\title{
The Effect of Yeast Strain, Immobilisation, and Ageing Time on the Amount of Free Amino Acids and Amino Acids in Peptides of Sparkling Wines Obtained from cv. Dimrit Grapes
}

\author{
A. Bozdoğan ${ }^{1 *}$, A. Canbaş² \\ (1) Osmaniye Korkut Ata University, Faculty of Engineering, Department of Food Engineering, 80000 - Osmaniye, Turkey \\ (2) Cukurova University, Faculty of Agriculture, Department of Food Engineering, 01330- Adana, Turkey.
}

Submitted for publication: April 2012

Accepted for publication: July 2012

Key words: amino acid, peptide, bottle-fermented sparkling wine, immobilisation, Dimrit

\begin{abstract}
In this study, the influence of yeast strain, immobilisation, and ageing time with yeast were examined in relation to the amount of free amino acids and amino acids in the peptides of wines. Free and immobilised Saccharomyces bayanus and Saccharomyces cerevisiae yeasts were used in sparkling wine production. Samples from the base wine and sparkling wines were taken at 20, 40, 90, 180, 270 and 365 days of ageing with yeast. It was observed that the majority of differences between wine samples in terms of the amount of free amino acids and amino acids in peptides were due to ageing time. The amount of total free amino acids in wine made with Saccharomyces cerevisiae was higher than in that made with Saccharomyces bayanus. In addition, no differences were observed between free and immobilised yeast in terms of amino acids and amino acids in peptides.
\end{abstract}

\section{INTRODUCTION}

Sparkling wine produced by the traditional method is characterised by the re-fermentation of a base wine in a bottle to which yeast and sugar are added. Wine obtained in this way is aged with yeasts for a variable time period of several months for wines manufactured by the traditional method (Charpentier \& Feulliat, 1993; Martinez-Rodriquez $\&$ Polo, 2000). During ageing, the yeast undergoes autolysis, and several compounds, such as nitrogen compounds, volatile substances, carbohydrates and lipids, are released. These compounds significantly change the characteristics of the wine and affect its sensory quality (MartinezRodriquez \& Polo, 2000; Moreno-Arribas et al., 2005). Nitrogen compounds are among the major compounds. They are formed mainly by the peptides and free amino acids. Although numerous authors have studied the composition of the amino acids and peptides of sparkling wines and the changes in these compounds in ageing time with yeast in recent years (Feulliat \& Charpentier, 1982; MorenoArribas et al., 1996, 1998), only one study has examined how yeast strain affects free amino acids and amino acids in peptides during the second fermentation and ageing with yeast (Martinez-Rodriquez et al., 2002). In this study they detected differences between wines made with four yeasts. Some authors have studied the influence of yeast strain on free amino acid and peptides in a model solution (Martinez-Rodriquez et al., 2001; Perrot et al., 2002). On the other hand, the use of immobilised yeast cells in sparkling wine production is a rapidly expanding research area. This technique has some advantages, such as easy clarification and removal of cells for sparkling wine produced in a bottle (Divies et al., 1994; Kourkoutas et al., 2004). Several studies (Fumi et al., 1987, 1988; Pisinelli et al., 1989) have noted the effect of immobilised yeast on the chemical composition of sparkling wine. However, to our knowledge, there have been only two studies for determining the changes in free amino acids (Yokotsuka et al., 1997) and amino acids in peptides in sparkling wine (Bozdoğan \& Canbaş, 2011).

Dimrit is one of most common black grape variety grown in Nevsehir-Urgup (Cappadocia) and it is used for the production of wine in Turkey (Canbaş, 1978). No previous studies exist regarding the composition of free amino acids and peptides in base wine and sparkling wine obtained from Dimrit.

The aim of this study was to examine the influence of the yeast strain, immobilisation and ageing time on the evaluation of free amino acids and amino acids in peptides in sparkling wine.

\section{MATERIAL AND METHODS}

Reagent and standards

HPLC-grade methanol and acetonitrile amino acid standards were purchased from Merck (Darmstadt, Germany) and Biomedicals (Eschwege, Germany), and DEEMM was

*Corresponding author: e-mail: bozdogan@osmaniye.edu.tr [Tel: +90 328825 18 18; Fax: +90 3288250097$]$

Acknowledgements: The authors would like to thank the Scientific and Technical Research Council of Turkey (Project No: TUBITAK-TOVAG 3391) and the Academic Research Projects Unit of Cukurova University (Project NO: ZF-2006 D8) for financial support 
purchased from Merck (Darmstadt, Germany). Ultrapure water was obtained from a Milli-Q system from Millipore (Milford, MA, USA). All the other reagents were of analytical grade.

\section{Yeast}

Starters were prepared using Saccharomyces bayanus EC 1118 (a commercial strain, Lallemand, Spain) and Saccharomyces cerevisiae NCYC 482 from the National Collection of Yeast Cultures, England. The yeast was used both in a free-cell condition and in an immobilised one.

\section{Sparkling winemaking}

Healthy grapes of cv. Dimrit were harvested from the Nevsehir-Urgup province in 2004. The grapes were transported to the Pilot Winery of the Department of Food Engineering, Faculty of Agriculture, University of Cukurova. Without crushing, the grapes were directly pressed in a horizontal press and $30 \mathrm{mg} / \mathrm{L}$ of sulphur dioxide was added. The juice was settled at $15^{\circ} \mathrm{C}$ for $24 \mathrm{~h}$ and then racked. The musts were fermented $\left(18^{\circ} \mathrm{C}\right)$ with a commercial S. cerevisiae (0.2 g/L) 'Zymoflore VL1' (Bordeaux, France). After the alcoholic fermentation in stainless steel tanks (250 $\mathrm{L})$, the wines were racked and sulphur dioxide $(50 \mathrm{mg} / \mathrm{L})$ was added. The wines were then stored at $15^{\circ} \mathrm{C}$ in a stainless steel tank. Later, the wine was filtered through a membrane filter $(0.45 \mu \mathrm{m})$ and $30 \mathrm{mg} / \mathrm{L}$ of sulphur dioxide was added.

The physical and chemical base wine parameters are as follows: density 0.9912 , ethanol $11.46(\mathrm{v} / \mathrm{v})$, extract $15.4(\mathrm{~g} / \mathrm{L})$, total acidity $4.5(\mathrm{~g} / \mathrm{L}$, as tartaric acid), pH 3.31 , volatile acidity $0.20(\mathrm{~g} / \mathrm{L}$, as acetic acid), reducing sugar 0.96 $(\mathrm{g} / \mathrm{L})$, free $\mathrm{SO}_{2} 11.52(\mathrm{mg} / \mathrm{L})$, total $\mathrm{SO}_{2} 91.1(\mathrm{mg} / \mathrm{L})$, protein $8.20(\mathrm{mg} / \mathrm{L})$.

Free yeast cells or beads containing $2 \times 10^{6}$ cells $/ \mathrm{mL}$ of viable yeast cells were added to the base wine containing $24 \mathrm{~g} / \mathrm{L}$ saccharose. A secondary fermentation was done at 16 to $18^{\circ} \mathrm{C}$. All fermentations were conducted in triplicate. Samples were taken from the base wine (time 0) and at 20, 40, 90, 180, 270 and 365 days of ageing with yeasts. All the analyses were conducted in duplicate on wines that had been centrifuged for $15 \mathrm{~min}$. at $5000 \mathrm{x} \mathrm{g}$.

\section{Yeast cell growth and immobilisation}

Yeast cells were harvested by centrifugation at $2500 \mathrm{x} \mathrm{g}$ for $10 \mathrm{~min}$ and were washed once in sterile water. The yeast cells were mixed with $2 \% \mathrm{Na}$-alginate and added dropwise with a peristaltic pump $(2.5 \mathrm{ml} / \mathrm{min})$ into a sterile solution of $0.5 \mathrm{M} \mathrm{CaCl}_{2}$. After two hours, the beads that formed (2 to 3 $\mathrm{mm}$ diameter) were washed with sterilised water, and $4.5 \mathrm{~g}$ gel beads containing $2 \times 10^{6}$ cells $/ \mathrm{ml}$ wine were used for each bottle (Fumi et al., 1988; Ciani \& Ferraro, 1998).

\section{Acidic hydrolysis}

Acidic hydrolysis of the sample containing peptides was conducted in the presence of $\mathrm{HCl}(6 \mathrm{M})$ at $110^{\circ} \mathrm{C}$ after $24 \mathrm{~h}$.

\section{Isolation of peptide fraction}

After centrifugation as described above, the sample was ultrafiltered on a $10000 \mathrm{Da}$ cut-off membrane (Amicon, Epernon, France). The ultrafiltrate was kept at $-20^{\circ} \mathrm{C}$ for amino acid and peptide analysis.

\section{Amino acid and peptides analysis}

The L-aspartic acid, L-glutamic acid, L-asparagine, DLserine, L-glutamine, L-histidine, L-threonine, L-arginine, DL-alanine, $\gamma$-amino butyric acid (GABA), DL-valine, DL-tryptophan, L-phenylalanine, L-isoleucine, L-leucine, ethanolamine, DL-methionine, L-tyrosine and L-lysine were analysed on an Agilent 1100 HPLC with photodiode array detector. Samples were submitted to derivatisation with DEEMM. All separations were performed on an ACE $\mathrm{C}_{18}$ column particle size $5 \mu \mathrm{m}(250 \mathrm{~mm} \times 4.6 \mathrm{~mm})$. Solvents and gradient conditions were as described by Hermosin et al. (2003) and Gómez-Alonso et al. (2007). For detection, a photodiode array detector monitored at $280 \mathrm{~nm}$ was used.

The amino acid composition of the peptides was calculated as the differences between the amino acid content in the fractions before and after hydrolysis. Asparagine and glutamine were partially converted to aspartic acid and glutamic acid during acid hydrolysis. Thus, these compounds are reported as Asx and Glx respectively (IUPAC-IUB, 1972).

\section{Chemical analysis of the wines}

Total acidity, volatile acidity, $\mathrm{pH}$, free and total $\mathrm{SO}_{2}$, density, ethanol, extract and reducing sugars $(\mathrm{g} / \mathrm{L})$ were analysed (Ough \& Amerine, 1988; Office International De La Vigne Et Du Vin, 1994). Protein contents were determined according to the Bradford method using bovine serum albumin as a standard (Marchall et al., 1997).

\section{Statistical methods}

The statistical methods used for the data analysis were two-way analysis of variance (ANOVA) to test the effect of the two factors studied (yeast strains and ageing time) and Duncan's test for mean comparisons. Furthermore, Cluster analysis (Ward's method) was used to discover the natural groupings of the wine samples. SPSS for Windows (version 10.0, SPSS Inc., Chicago, USA) was used for data processing.

\section{RESULTS AND DISCUSSION}

Changes in free amino acids and amino acids in peptides during ageing with free and immobilised yeasts

\section{Free amino acids}

Two-way analysis of variance was used to study the differences between the amount of free amino acids due to yeast strain and ageing time. The results are summarised as mean values and standard deviations in Table 1 . The most abundant amino acids were GABA, ethanolamine, asparagine + serine, and glutamic acid.

Moreno-Arribas et al. (2000) reported that alanine, GABA, arginine and glutamic acid were the major amino acids for base wines made of the Xarella, Parellada, Macabeo and Chardonnay grape varieties. Soufleros et al. (2003) found that arginine, GABA, lysine, alanine and glutamic acid were among the major primary amino acids of six Greek grape varieties. Bozdoğan and Canbaş (2011) found that asparagine, serine, ethanolamine and GABA were the major 


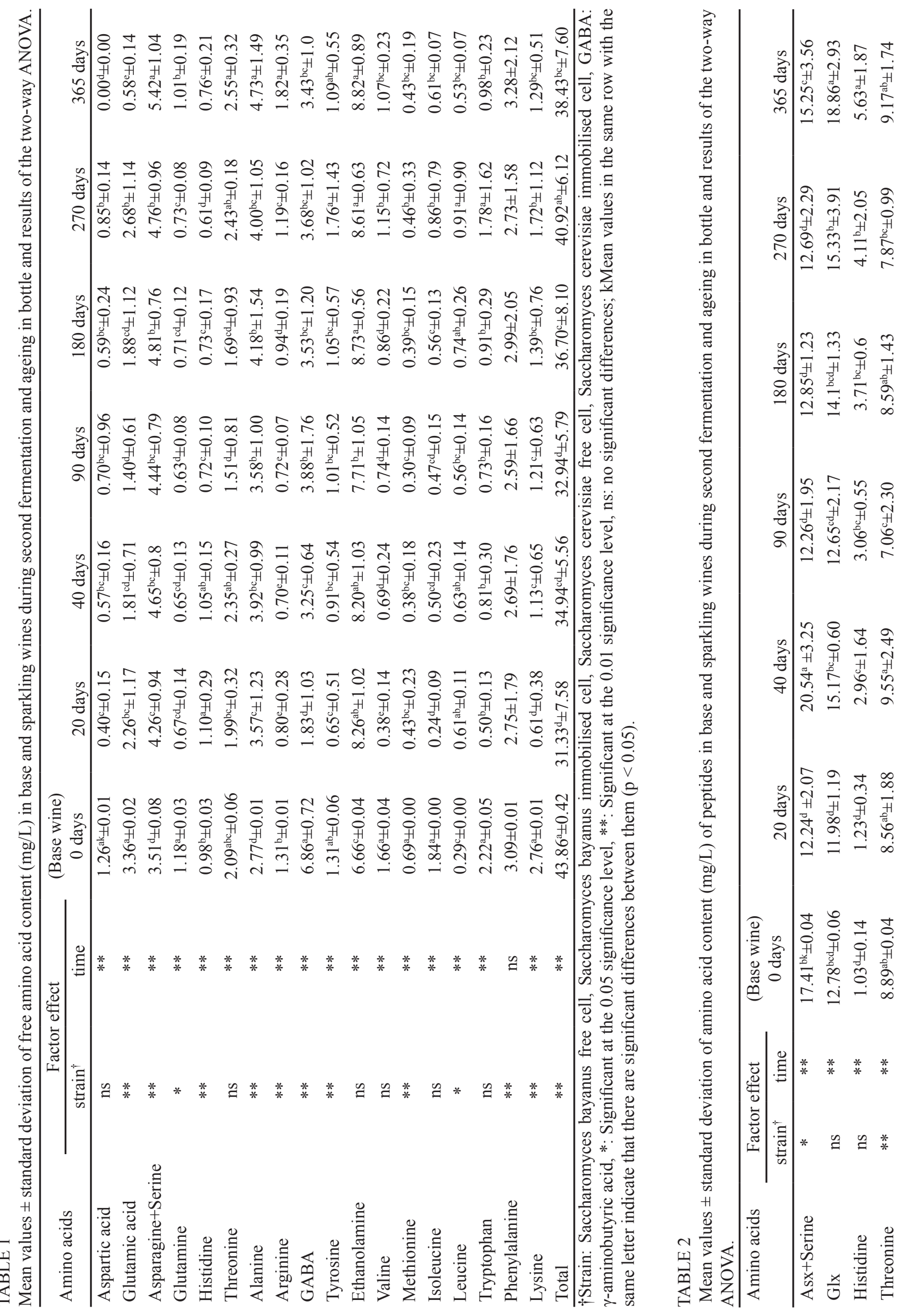




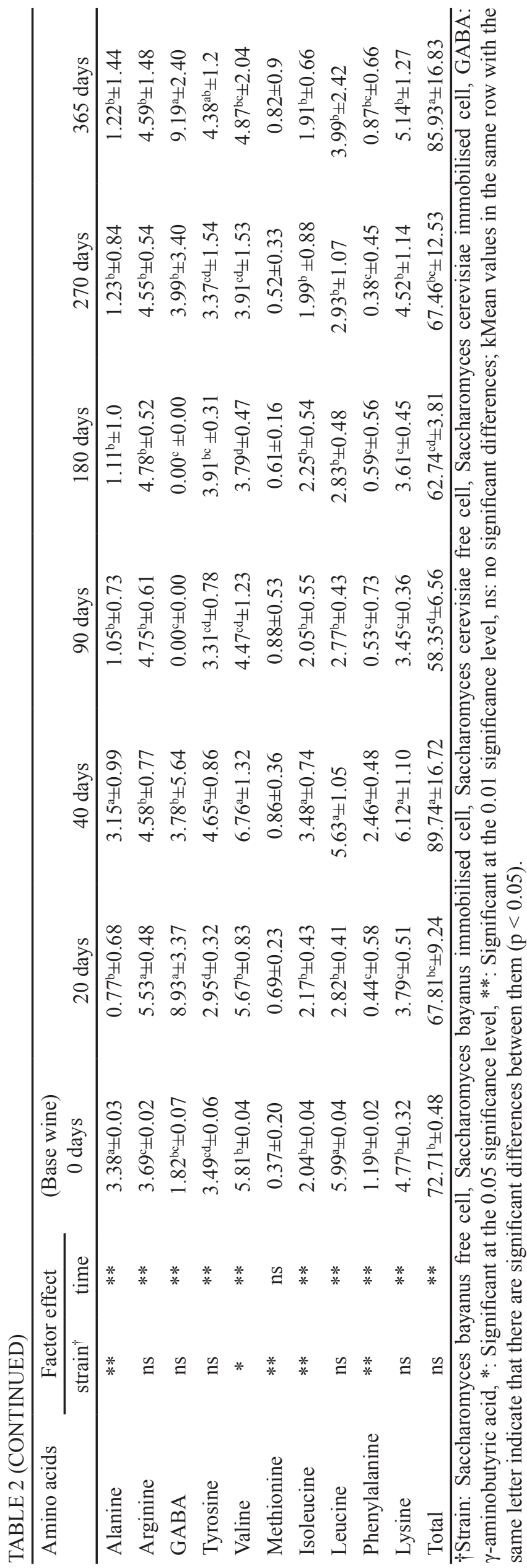

amino acids in base wines made from the Emir grape variety.

ANOVA analysis showed that yeast strains significantly affected all free amino acids, except for aspartic acid, threonine, ethanolamine, valine, isoleucine and tryptophan. In addition, it was observed that yeast strains significantly influenced $(\mathrm{p}<0.01)$ total free amino acid. The statistical analysis showed that the total free amino acid in the wine from free $S$. cerevisiae and immobilised $S$. cerevisiae had a mean content of $42.47 \mathrm{mg} / \mathrm{L}$ and $39.58 \mathrm{mg} / \mathrm{L}$ respectively, and that it was significant higher $(\mathrm{p}<0.01)$ than that in the wine from immobilised $S$. bayanus $(34.46 \mathrm{mg} / \mathrm{L})$ and free S. bayanus $(31.56 \mathrm{mg} / \mathrm{L})$. The total free amino acid content was higher in wine from free $S$. cerevisiae $(57.68 \mathrm{mg} / \mathrm{L})$ and immobilised S. cerevisiae $(57.45 \mathrm{mg} / \mathrm{L})$. This situation could be explained by the fact that $S$. cerevisiae accrued more autolysis than S. bayanus. Bozdoğan and Canbaş (2011) reported that the greatest total amino acids were found in wines inoculated with $S$. cerevisiae yeast. Yokotsuka et al. (1997) reported that there were no differences between wines made with free and immobilised yeast in terms of free amino acids. Martinez-Rodriquez et al. (2002) observed differences between the free amino acids of wine made with free yeasts.

In the period between 0 and 20 days, aspartic acid, glutamic acid, glutamine, threonine, arginine, GABA, tyrosine, valine, methionine, isoleucine, tryptophan and lysine decreased. The decrease in amino acids was due to consumption by yeasts at this stage (Feulliat \& Charpentier, 1982; Martinez-Rodriquez et al., 2002; Martinez-Rodriquez $\&$ Polo, 2000). The presence of viable cells was high in wine during this period of time. In the period between 20 and 365 days of ageing with yeast, there were significant differences in the amino acids asparagine+serine, glutamine, threonine, alanine, arginine, GABA, tyrosine, ethanolamine, valine, isoleucine and lysine, which increased, and glutamic acid, histidine and leucine, which decreased.

The results showed that the amount of most free amino acids and total free amino acids was significantly influenced by ageing time $(p<0.01)$. It was observed that the total free amino acid content decreased after 20 days of ripening and re-increased until day 365 .

The changes in free amino acids were not the same at each stage of production. The increase in these compounds may be associated with a physiological response to the lack of nutrients in the presence of viable cells in the medium, and also due to the autolysis process after the decline of viable cells (Martinez-Rodriquez et al., 2002; Hidalgo et al., 2004). The decrease in these compounds can be explained by deamination reactions of amino acids, or by participation in the formation of different compounds (Feulliat \& Charpentier, 1982; Herraiz et al., 1993; Martinez-Rodriquez et al., 2002).

Cluster analysis was carried out with the free amino acids studied in sparkling wines. The results are given in Fig. 1. Two main groups were obtained, one consisting of 365-day wines clearly separated from the rest of the wines, and the other consisting of the majority of the wines grouped according to ageing time. Martinez-Rodriquez et al. (2002) reported that there are groupings due to the yeast strain and ageing time factor according to free amino acids. 


\section{Amino acids in peptides}

Table 2 show the amount of amino acids in peptides in the base wine and sparkling wines at different ageing times. The tables show the results of the two-way analysis of variance. Asx + Serin, Glx, threonine and leucine are the principal amino acids in the base wine peptides. Acedo et al. (1994) found that the major amino acids in peptides are glutamic and aspartic acids, serine, glycine, alanine and lysine. Moreno-Arribas et al. (1998) detected the major amino acids in the peptides of base wine to be lysine, glycine, GABA, proline, threonine, serine and Asx. Bozdoğan and Canbaş (2011) reported that Asx+Serine, Glx, threonine and lysine were the most abundant amino acids in peptides of base wines of Emir.

The results of the ANOVA revealed that the amount of amino acids in the peptides was not significantly influenced by yeast strain. Only Asx+Serine, threonine, alanine, valine, methionine, isoleucine and phenlyalanine were influenced by the yeast strain. On the other hand, the ageing time factor significantly affected the amount of amino acids in the peptides, except for methionine.
Asx + Serine, Glx, alanine, tyrosine, leucine, phenlyalanine and lysine decreased from the base wine to the wine after 20 days. This may be explained by the consumption of peptides by viable yeasts in an amino acid-deficient medium at this stage (Moreno-Arribas et al., 1996; Hidalgo et al., 2004). On the other hand, in the wines between 20 and 365 days of ageing with yeasts, Asx+Serine, Glx, histidine, alanine, tyrosine, phenylalanine and lysine increased. The increase in peptides is associated with the yeast autolysis process, during which the release of compounds from the yeast and the breakdown of these compounds due to enzyme activities occur during ageing (Feulliat \& Charpentier, 1982; Moreno-Arribas et al., 1996; Hidalgo et al., 2004).

Cluster analysis was performed on the data of the amino acids in the peptides of the wines. The resulting dendrograms are shown in Fig. 2. Two main groups were obtained: 365day wines appear in one group, and the remaining wines appear in the other group. Clusters were observed due to the ageing time, but there were no clusters based on yeast strain factor. Moreno-Arribas et al. (1998) detected that the samples were grouped according to ageing time.

\section{Linkage Distance}

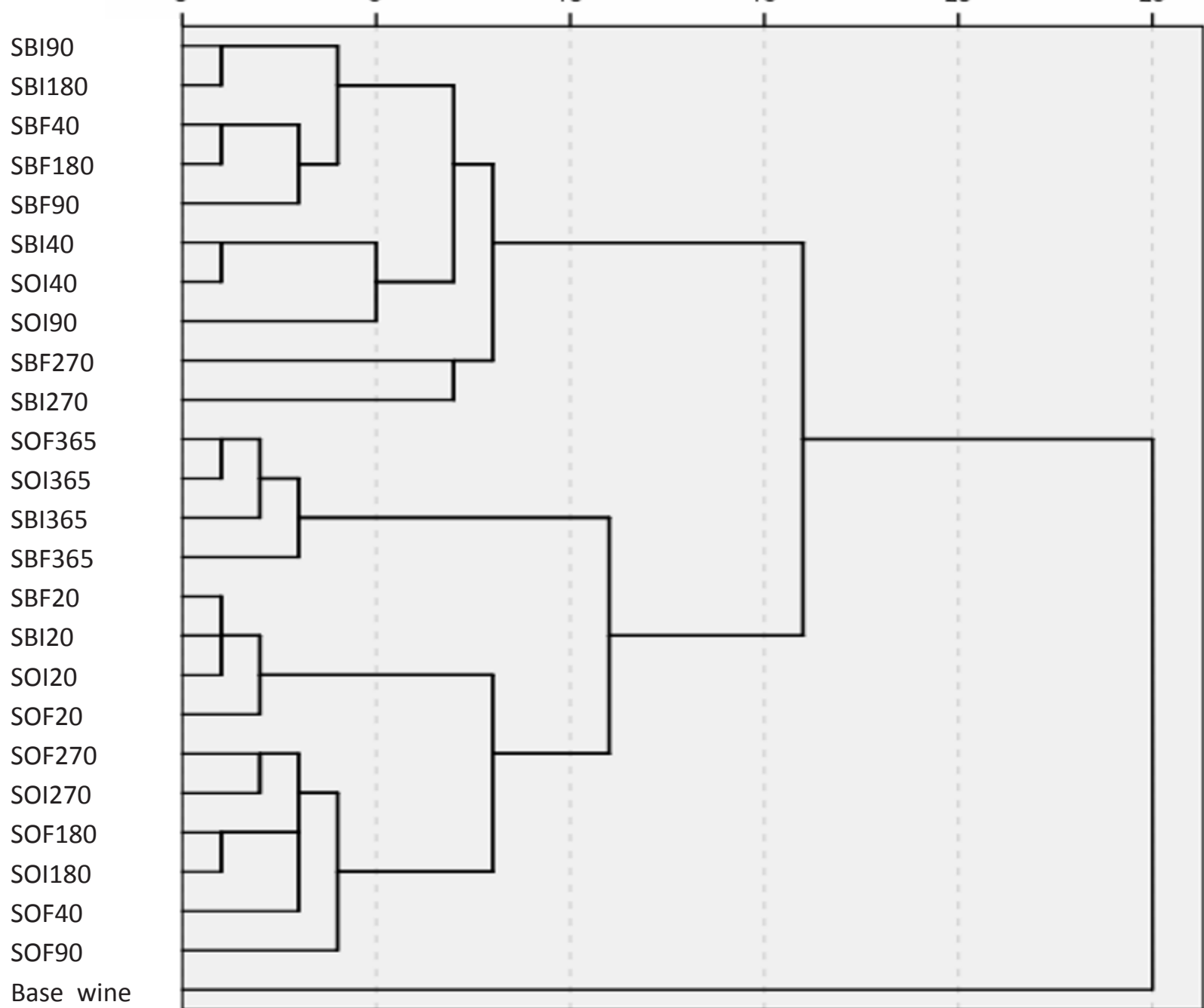

FIGURE 1

Dendrogram of the 25 wine samples according to concentration $(\mathrm{mg} / \mathrm{L})$ of the free amino acids. (SBI $=\mathrm{S}$. bayanus immobilised cells, $\mathrm{SBF}=\mathrm{S}$. bayanus free cells, $\mathrm{SCI}=\mathrm{S}$. cerevisiae immobilised cells, $\mathrm{SCF}=\mathrm{S}$. cerevisiae free cells) . 
Linkage Distance

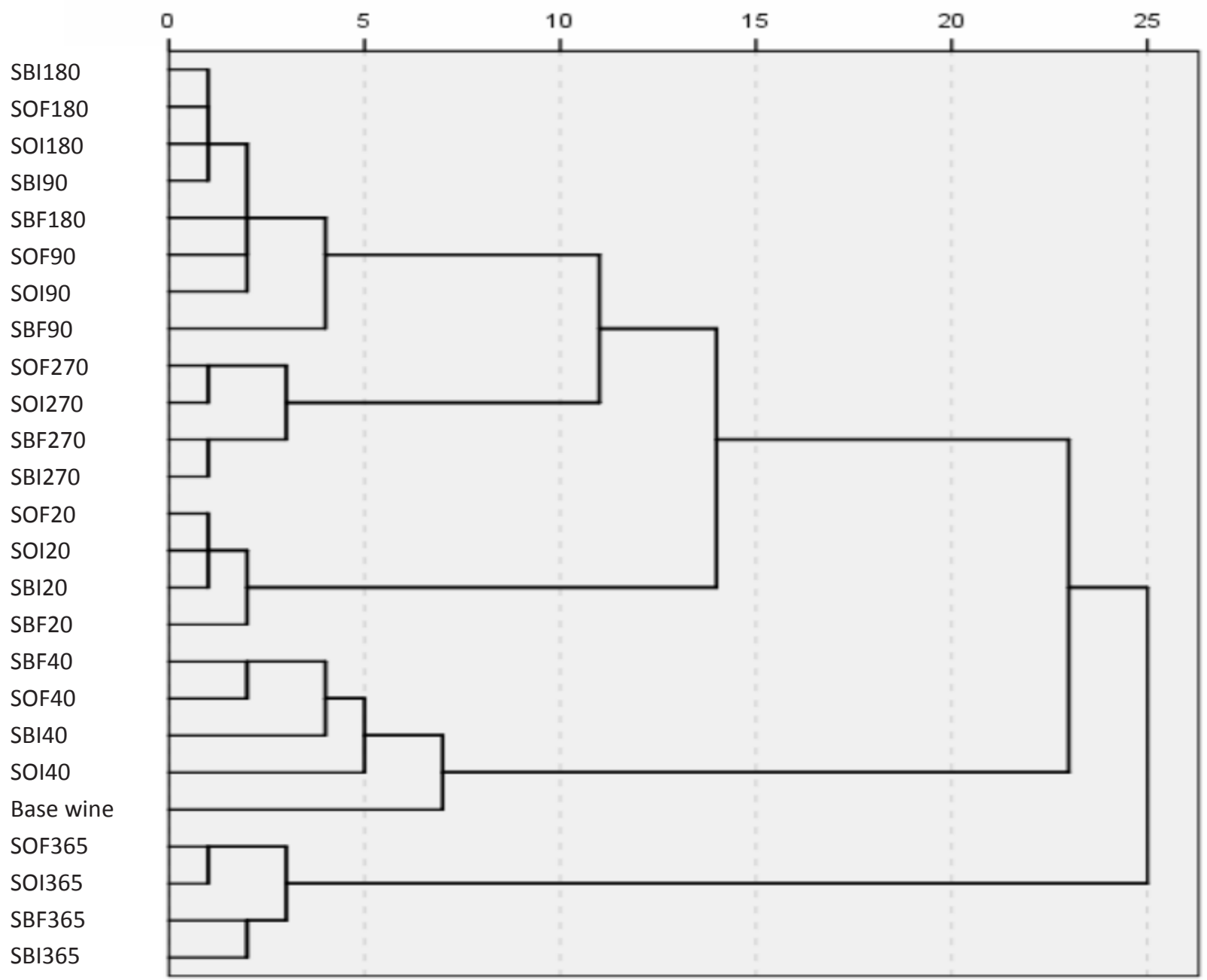

FIGURE 2

Dendrogram of the 25 wine samples according to concentration $(\mathrm{mg} / \mathrm{L})$ of the amino acids in peptides. $(\mathrm{SBI}=\mathrm{S}$. bayanus immobilised cells, $\mathrm{SBF}=\mathrm{S}$. bayanus free cells, $\mathrm{SCI}=\mathrm{S}$. cerevisiae immobilised cells, $\mathrm{SCF}=\mathrm{S}$. cerevisiae free cells) .

\section{CONCLUSIONS}

The results show that the amount of free amino acids and amino acids in the peptides of wine samples are influenced significantly by ageing time on yeast. The changes in free amino acids and amino acids in peptides are not the same at each stage of production. The yeast strain was affected by the amount of free amino acids in the wines The total free amino acids in the wines made with $S$. cerevisiae were higher than in wines made with $S$. bayanus. Significant differences in free amino acids and peptides content were not found between the free and immobilised yeasts used.

\section{LITERATURE CITED}

Acedo, M.I., Pueyo, E. \& Polo, M.C., 1994. Preliminary studies on peptides in wine by HPLC. Am. J. Enol. Vitic. 45, 167-172.

Bozdoğan, A. \& Canbaş, A., 2011. Influence of yeast strain, immobilization and aging time on the changes of free amino acids and amino acids in peptides in bottle-fermented sparkling wines obtained from Vitis vinifera cv. Emir. Int. J. Food Sci. Tech. 46, 1113-1128.

Canbaş, A., 1978. Nevşehir-Ürgüp Çevresi Dimrit Üzümlerinden Daha İyi Kalitede Şarap Elde Etme Olanakları Üzerinde Teknolojik Araştırmalar (Doçentlik Tezi), Ç.Ü. Ziraat Fakültesi.
Charpentier, C. \& Feulliat, M., 1993. Wine Microbiology and Biotechnology, Ed: Fleet, G.H., Harwood Academic Publishers, Chur, Switzerland.

Ciani, M. \& Ferrora, L., 1998. Combined use of immobilized Candida stellata cells and Saccharomyces cerevisiae to improve the quality of wines. J. Appl. Microbiol. 85, 247-254.

Divies, C., Cachon, R., Cavin, J.F. \& Prevost, H., 1994. Theme 4: immobilized cell technology in wine production. Crit. Rev. Biotechnol. 14 135-153.

Feulliat, M. \& Charpentier, C., 1982. Autolysis of yeasts in Champagne. Am. J. Enol. Vitic. 33, 6-13.

Fumi, D.M., Trioli, G. \& Colagrande, O., 1987. Preliminary assessment on the use of immobilized yeast cells in sodium alginate for sparkling wine processes. Biotechnol. Lett. 9, 339-342.

Fumi, D.M., Trioli, G., Colombi, M.G. \& Colagrande, O., 1988. Immobilization of $S$. cerevisiae in calcium alginate and its application to bottle-fermented sparkling wine production. Am. J. Enol. Vitic. 39, $267-$ 272 .

Gómez-Alonso, S., Hermosin-Gutiérrez, I. \& Garcia-Romero, E., 2007. Simultaneous HPLC analysis of biogenic amines, amino acids, and ammonium ion as aminoenone derivatives in wine and beer samples. J. Sci. Food Agr. 55, 608-613. 
Hermosin, I., Rosa, M.C. \& Dolores Cabezudo, M., 2003. Free amino acid composition and botanical origin of honey. Food Chem. 83, 263-268.

Herraiz, T. \& Ough, C.S., 1993. Formation of ethyl esters of amino acids by yeasts during the alcoholic fermentation of grape juice. Am. J. Enol. Vitic. $44,41-48$.

Hidalgo, P., Pueyo, E., Pozo-Bayon, M.A., Martinez-Rodriquez, A.J., Martin-Alvarez, P. \& Polo, M.C., 2004. Sensory and analytical study of rosé sparkling wines manufactured by second fermentation in the bottle. J. Agric. Food Chem. 52, 6640-6645.

IUPAC-IUB. 1972. Commission on biochemical nomenclature, symbols for amino-acid derivatives and peptides recommendations (1971). J. Biological Chem. 247, 977-983.

Kourkoutas, Y., Bekatorou, A., Banat, I.M., Marchant, R. \& Koutinas, A.A., 2004. Immobilization technologies and support materials suitable in alcohol beverages production: a review. Food Microbiol. 21, 377-397.

Marchall, R., Seguin, V. \& Maujean, A., 1997. Quantification of interferences in the direct measurement of proteins in wines from the Champagne region using the Bradford Method. Am. J. Enol. Vitic. 48, 303-309.

Martinez-Rodriquez, A.J. \& Polo, M.C., 2000. Enological aspects of yeast autolysis. Rec. Res. Devel. Microbiol. 4, 285-301.

Martinez-Rodriquez, A., Carrascosa, A.V. \& Polo, M.C., 2001. Release of nitrogen compounds to the extracellular medium by three strains of $S$. cerevisiae during induced autolysis in a model wine system. Int. J. Food Microbiol. 68, 155-160.

Martinez-Rodriquez, A., Carrascosa, A.V., Martin-Alvarez, P.J., MorenoArribas, V. \& Polo, M.C., 2002. Influence of the yeast strain on the changes of the amino acids, peptides and proteins during sparkling wine production by the traditional method. J. Ind. Microbiol. Biot. 29, 314-322.
Moreno-Arribas, V., Pueyo, E. \& Polo, M.C., 1996. Peptides in musts and wines. Changes during the manufacture of Cavas (sparkling wines). J. Agric. Food Chem. 44, 3783-3788.

Moreno-Arribas, V., Pueyo, E., Polo, M.C. \& Martin-Alvarez, P.J., 1998. Changes in the amino acid composition of the different nitrogenous fractions during the aging of wine with yeasts. J. Agric. Food Chem. 46, 4042-4051.

Moreno-Arribas, V., Pueyo, E., Nieto, F.J., Martin-Alvarez, P.J. \& Polo, M.C., 2000. Influence of the polysaccharides and the nitrogen compounds on foaming properties of Sparkling Wines Food Chem. 70, 309-317.

Moreno-Arribas, V., Pueyo, E. \& Polo, M.C., 2005. Winemaking biochemistry and microbiology: current knowledge and future trends. Crit. Rev. Food Sci. Nutr. 45, 265-285.

Office International De La Vigne Et Du Vin, 1994. OIV standard for the international wine competitions. Bull. O.I.V. 67, 551-597.

Ough, C.S. \& Amerine, M.A., 1988. Methods for analysis of musts and wines. John Wiley and Sons, New York.

Perrot, L., Charpentier, M., Charpentier, C., Feulliat, M. \& Chassagne, D., 2002. Yeast adapted to wine: nitrogen compounds released during induced autolysis in a model wine. J. Ind. Microbiol Biot. 29, 134-139.

Pisinelli, A.M., Favati, F., Crapisi, A., Borin, G. \& Spettolli, P., 1989. The free amino acid content of bottle-fermented Moscato Bianco sparkling wine by immobilized yeasts. Yeast 5, 113-116.

Soufleros, E.H., Bouloumpasi, E., Tsarchopoulos, C. \& Biliaderis, C.G., 2003. Primary amino acid profiles of Greek white wines and their use in classification according to variety, origin and vintage. Food Chem. 80, 261273 .

Yokotsuka, K., Yajima, M. \& Matsudo, T., 1997. Production of bottlefermented sparkling wine using yeast immobilized in double-layer gel beads or strands. Am. J. Enol. Vitic. 48, 471-481. 